\title{
ANALISIS DEIKSIS DALAM BAHASA GORONTALO
}

\author{
Aryati Hamzah $^{1}$, William I. S. Mooduto ${ }^{2}$, Imam Mashudi ${ }^{3}$ \\ ${ }^{1,2,3}$ Universitas Bina Mandiri Gorontalo, Indonesia
}

DOI: 10.23917/humaniora.v22i1.9873

Submit: 12 Januari 2020. Revisi: 12 Januari 2021. Diterima: 18 Januari 202.

Available Online: 27 Januari 2021. Periode Terbit: Februari 2021.

\begin{tabular}{l}
\hline Keywords \\
\hline deixis, \\
language description, \\
the Gorontalo language
\end{tabular}

\section{Corresponding}

Author

Aryati Hamzah

Afiliasi

Negara

Email:

aryati.hamzah@ubmg.

ac.id

Telp:

$+6285239793997$

\section{Abstract}

This research aims to describe the use of deixis in Gorontalo Language. This research was conducted in two stages namely the stage of preparation and implementation of the research. This research was conducted for 1 year. The result of the research showed that the form and meaning of deixis are person deixis, time and place. Persona deixis is divided into several types is deixis of first-person singular (wa'u '1sg', watiya '1sg'), deixis of the first person plural (ami '1pl.excl'), deixis of the second person singular (yi'o '2sg', tingoli ' $2 \mathrm{sg}$ '), deixis of the second person plural (tingoli ' $2 p l$ ', timongoli ' $2 p l$ '), and deixis of the third person singular (tio ' $3 \mathrm{sg}$ ') and timongolio ' $3 p l$ ' as a deixis of the third person plural. Whereas, deixis of place are teye, teyamai 'here', tetomota 'there' this means to show the location of the room and the place of conversation or interlocutor. Deixis time among others yindhie 'today', lombu 'tomorrow', olango 'yesterday', dumodupo 'morning', mohulonu 'afternoon', hui 'night' which have the meaning to show the time when the speech or sentence is being delivered.

\begin{tabular}{ll}
\hline Kata Kunci & Abstrak \\
\hline deiksis, & Penelitian ini bertujuan untuk mendeskripsikan penggunaan \\
bahasa Gorontalo & deiksis dalam Bahasa Gorontalo. Penelitian ini dilaksanakan \\
& dengan dua tahap, yaitu tahap persiapan dan tahap pelaksanaan \\
& penelitian. Penelitian ini dilakukan selama I tahun. Hasil \\
& penelitian menunjukkan bahwa bentuk dan makna deiksis yang \\
& digunakan dalam bahasa Gorontalo, yaitu deiksis persona, \\
& waktu, dan tempat. Deiksis persona terbagi dalam beberapa \\
& jenis, yaitu deiksis persona pertama tunggal (wa'u/aku, wa- \\
& tiya/saya), deiksis persona pertama jamak (ami/kami), deiksis \\
& persona kedua tunggal (yi’o/kamu, tingoli/kamu), deiksis per- \\
& sona kedua jamak (tingoli/kalian, timongoli/kalian), dan deiksis \\
& persona ketiga tunggal (tio/dia) serta timongoliyo (mereka) se- \\
& bagai deiksis persona ketigajamak. Adapun deiksis tempatyaitu \\
& teye, teyamayi/di sini, temota/di sana yang berarti menunjukkan \\
& lokasi ruang dan tempatpembicaraan serta lawan bicara. Deik- \\
& sis waktu antara lain yindhie/sekarang, lombu/besok, \\
& olango/kemarin, dumodupo/pagi, mohulonu/siang, dan \\
& hui/malam yang memiliki makna untuk menunjukkan waktu pan- \\
& dang ketika tuturan kata/kalimat disampaikan.
\end{tabular}




\section{PENDAHULUAN}

Bahasa merupakan media komunikasi yang digunakan untuk menyampaikan pesan dengan menggunakan simbol-simbol yang disepakati bersama bersama (Aminuddin, 2016; "Deiksis Pada Wacana Sarasehan Habib Dengan Masyarakat," 2017; Kesumawardani, 2015; Syamsurizal, 2015). Sebuah kata, apabila dirangkai berdasarkan urutan, akan membentuk kalimat yang bermakna dan mengikuti aturan atau tata bahasa yang berlaku dalam suatu komunitas atau masyarakat (Gustiasari, 2018; Sartini, 2009; Wiratno \& Santosa, 2014). Sementara itu, perkembangan bahasa adalah proses atau tahapan pertumbuhan bahasa ke arah yang lebih maju. Dengan mempelajari perkembangan bahasa, peserta didik diharapkan dapat berkomunikasi secara efektif dan memahami apa yang dirasakan atau diinginkan oleh komunitas bahasa.

Masyarakat yang merupakan makhluk sosial dalam kehidupan sehari-hari selalu berkomunikasi satu sama lain (Muslikhah Dwihartanti, 2004; Purnama, 2011; Wiratno \& Santosa, 2014). Komunikasi menjadi salah satu kebutuhan manusia sebagai makhluk sosial. Komunikasi merupakan suatu proses dalam menyampaikan informasi berupa pesan, ide, dan gagasan dari satu pihak ke pihak yang lain. Oleh karena itu, untuk melakukan komunikasi, manusia menggunakan bahasa, baik secara lisan maupun tulisan. Di masyarakat bahasa memberikan kemudahan yang sangat banyak bagi pemakainya dalam suatu proses komunikasi. Salah satu kemudahan tersebut adalah adanya sistem pengacuan atau referensi. Akan tetapi, adanya sistem pengacuan ini juga menyebabkan terjadinya kebingungan, ketidakjelasan, dan kesalahpahaman makna antarpengguna bahasa yang berkaitan dengan pemahaman makna ujaran dan acuan atau referen. Oleh karena itu, agar dapat memahami referen dari sebuah tuturan, seseorang harus mampu mengidentifikasi konteks dan situasi pertuturan (Santoso, T. et al, 2018). Untuk memahami referen, seseorang harus memahami tentang deiksis karena referen dan deiksis saling berhubungan erat.

Deiksis merupakan suatu kata, frasa atau ungkapan yang mempunyai rujukan yang berubah-ubah, tergantung pada siapa yang menjadi pembicara, waktu, dan tempat suatu bahasa dituturkan. Deiksis merupakan bentuk bahasa, baik dalam bentuk kata maupun dalam bentuk lainnya yang memiliki fungsi sebagai penunjuk hal atau fungsi tertentu. Dengan pengertian lain, deiksis dapat didefinisikan sebagai bentuk bahasa yang berupa acuan atau rujukan yang dapat berpindah atau berganti, tergantung pada siapa yang menjadi pembicara atau lawan bicara dan dapat pula bergantung pada waktu serta tempat dituturkannya kata tersebut. Dalam konteks deiksis, hal ini merupakan fenomena yang sangat jelas untuk menggambarkan dua hal dalam kehidupan komunikasi, yaitu hubungan antara bahasa dan konteks dalam bahasa itu sendiri.

Selanjutnya, menurut (Yuniarti, 2014) deiksis adalah kata atau kata-kata yang rujukannya tidak tetap, dapat berpindah-pindah dari satu wujud ke wujud yang lain dan menyatakan waktu, menyatakan tempat serta berupa kata ganti. Selanjutnya, 
pendapat lain mengemukakan bahwa deiksis terbagi dalam enam bagian, yaitu deiksis persona, deiksis tempat, deiksis penunjuk, deiksis waktu, deiksis wacana, serta deiksis sosial (Abidin et al., 2019; Halimah \& Hilaliyah, 2019; Merentek, 2016; Mustika, 2012). Dalam penelitian ini fokus kajian dikhususkan pada tiga jenis deiksis yaitu deiksis persona, deiksis, waktu, dan deiksis tempat.

Tujuan utama penelitian ini adalah untuk mendeskripsikan penggunaan deiksis dalam bahasa Gorontalo. Oleh karena itu, untuk memahami dan menentukan apakah sebuah ujaran atau tuturan bersifat deiksis atau tidak dibutuhkan pemahaman yang menyeluruh terhadap ujaran atau tuturan tersebut. Selain itu, dalam penggunaan deiksis dalam kehidupan sehari-hari, sering dijumpai berbagai penggunaan deiksis dalam berbagai hal misalnya dalam percakapan, surat kabar, pesan singkat dalam sosial media, serta karya-karya fiksi. Pada penelitian ini pula, lebih dititikberatkan penggunaan deiksis dalam percakapan, khususnya percakapan yang digunakan dalam komunikasi sehari-hari.

Deiksis merupakan salah satu kajian yang ada dalam pragmatik. Pragmatik merupakan cabang ilmu linguistic yang membahas tentang apa yang termasuk struktur bahasa sebagai alat komunikasi antara penutur dan pendengar, dan sebagai pengacuan tanda-tanda bahasa pada hal-hal ekstralingual yang dibicarakan (Jamil \& Yusof, 2015; Merentek, 2016; Suseno et al., 2017; Utama, 2012). Pragmatik terdiri dari dua hal yaitu sebagai ilmu karena merupakan cabang linguistik yang mempelajari bahasa yang berkaitan dengan pemakaiannya, dan sebagai keterampilan dalam berbahasa merupakan hubungan antara unsure bahasa dengan konteks dan situasi, yang artinya keterampilan pragmatik yaitu keterampilan penggunaan bahasa secara komunikatif.

Sementara menurut (Miranti, 2014; Nursalim \& Alam, 2019) Deiksis adalah suatu kata yang memiliki referen yang hanya dapat diidentifikasi dengan memperhatikan identitas si pembicara serta saat dan tempat diutarakannya tuturan yang mengandung unsur yang bersangkutan. Deiksis adalah kata-kata yang memiliki referen berubah-ubah atau berpindah-pindah (Kesumawardani, 2015b). Selanjutnya, deiksis juga adalah suatu cara untuk mengacu ke hakikat tertentu dengan menggunakan bahasa yang hanya dapat ditafsirkan menurut makna yang diacu (Haq, 2017; Muharomah, 2016; Nafisah, 2017; Darista Suparno, 2016; Darsita Suparno, 2020).

Deiksis terbagi menjadi lima macam, yaitu deiksis persona (orang), deiksis tempat, deiksis waktu, deiksis wacana, dan deiksis sosial. Kelima deiksis tersebut saling memengaruhi dan melengkapi satu sama lain. Penafsiran deiksis juga melibatkan konteks, seperti ilmu pragmatik sebagai induk kajiannya. Pemaknaan suatu bahasa, seperti karangan narasi, juga harus disesuaikan dengan konteksnya. Penggunaan bahasa yang kurang teratur dan tidak efektif akan menyebabkan kerancuan dan menimbulkan persepsi yang berbeda pada mitra tutur atau partisipan atau penerima bahasa. Akibatnya, kalimat tidak dapat dimengerti jika tidak 
diketahui siapa yang sedang mengatakan tentang apa, di mana, dan kapan. Referen setiap kata tersebut dapat berganti-ganti, tergantung pada konteksnya.

\section{METODE}

Penelitian ini menggunakan pedekatan deskripsi kualitatif yang mana mendeksripsikan hasil penelitian yang telah dilakukan. Selain itu instrumen yang digunakan dalam penelitian ini yaitu manusia dimana peneliti harus mampu, peka logis dan kritis dalam mengambil data. dalam melakukan penelitian ini, langkah awal yang dilakukan adalah dengan melakukan observasi awal. Setelah melakukan langkah ini, peneliti melakukan studi literatur dan permasalahan terkait analisis deiksis yang ada dalam bahasa Gorontalo. Setelah itu, peneliti menentukan metode yang tepat yang digunakan dalam penelitian ini. Dalam metode penelitian ini, beberapa aspek yang diperhatikan antara lain data dan sumber data, teknik pengumpulan data, serta analisis data.

\section{Data dan Sumber Data}

Data dalam penelitian ini merupakan bentuk dan jenis dari deiksis berupa deiksis persona, tempat dan waktu. Sumber data dalam penelitian ini adalah hasil tuturan yang diucakan secara langsung oleh masyarakat Gorontalo dalam beberapa konteks lawan bicara. Oleh karena itu subjek dari penelitian ini merupakan orang Gorontalo, sedangkan objek penelitian analisis adalah deiksis persona, tempat dan waktu yang dituturkan oleh masyarakat Gorontalo. Bentuk deiksis yang dipilih ini selanjutnya dijabarkan dan dipilih berdasarkan peran subjek penelitian dalam peristiwa bahasa sebagai pembicara, lawan bicara, maupun bertindak sebagai persona yang dibicarakan.

\section{Teknik Pengumpulan Data}

Metode maupun teknik pengumpulan data yang digunakan dalam penelitian ini merupakan analisis dokumentasi (recording) dengan teknik pencatatan data yang ada berdasarkan recording audio yang ada. Analisis dokumentasi dilakukan untuk mendapatkan data yang bersumber pada penutur asli yang berperan sebagai subjek penelitian. Analisis data berdasarkan recording data yang telah dilakukan oleh peneliti ketika penutur asli melakukan percakapan dengan lawan bicara. Peneliti merekam (recording) selanjutnya rekaman tersebut diformulasikan dalam bentuk tulisan yang dapat dibaca oleh orang lain.

\section{Analisis Data}

Alat pencatat metode yang digunakan dalam penelitian ini merupakan makna. Setiap tuturan maupun kalimat yang ditulis berdasarkan temuan data yang ada kemudian dikategorikan berdasarkan makna yang berbeda. Oleh karena itu, unit analisis dalam penelitian ini merupakan kalimat-kalimat. Teknik pragmatik digunakan sebagai sub jenis teknik dalam menentukan makna. Alat ini merupakan 
alat yang digunakan dalam menganalisis bentuk serta peran dari deiksis persona, tempat, dan waktu.

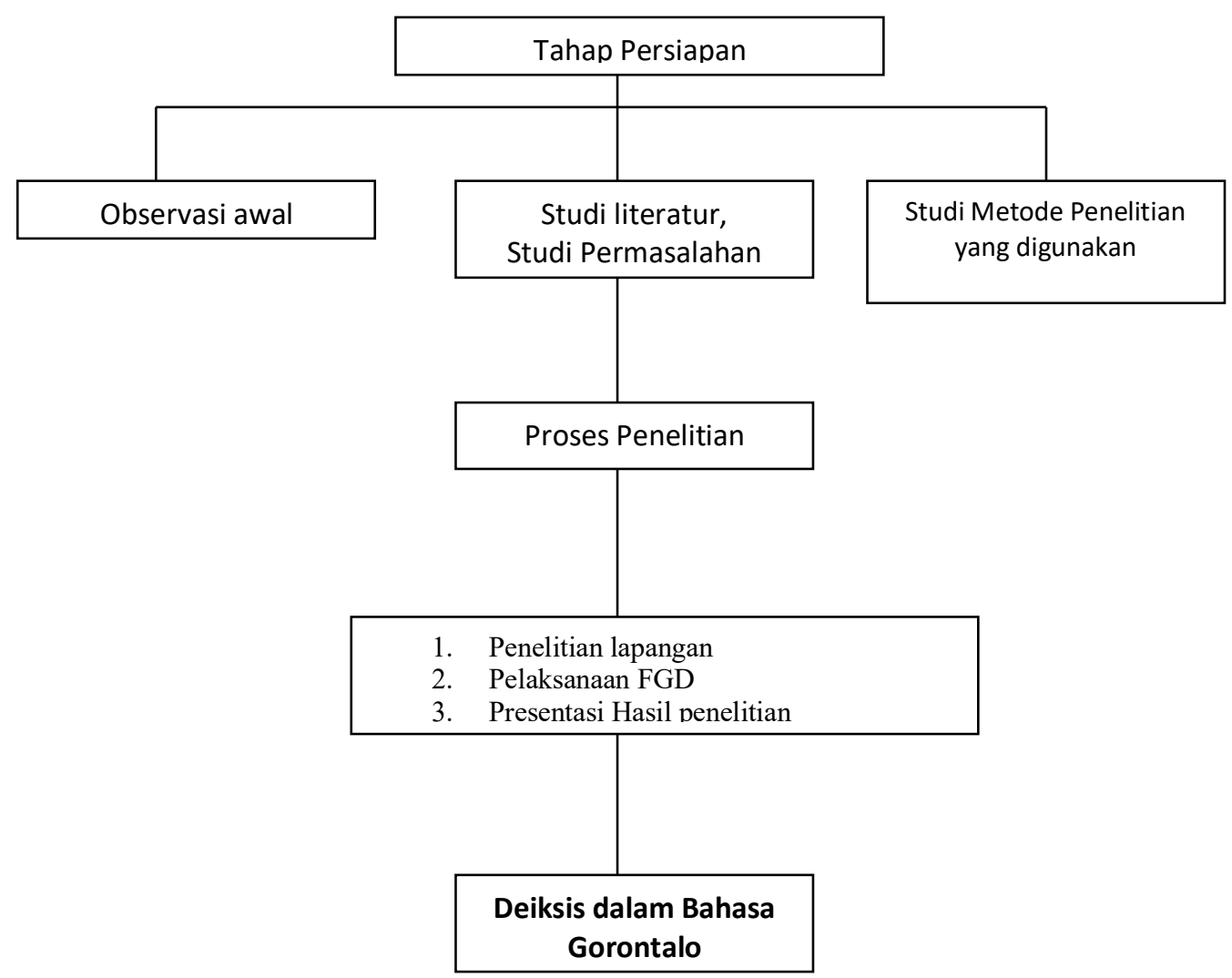

Gambar 1 Diagram Alur Penelitian

\section{HASIL}

Hasil dari analisis data yang ditemukan dalam penelitian ini berupa tuturan yang diucapkan oleh masyarakat Gorontalo dalam beberapa konteks lawan bicara, misalnya percakapan dengan orang asing, sepupu jauh, teman, keluarga maupun antara bibi dan keponakan. Pada bagian penyampaian tuturan yang disampaikan oleh masing-masing pembicara, terdapat bentuk deiksis persona, tempat, dan waktu. Selain itu, bagian paparan data juga mengidentifikasi jenis maupun makna dari deiksis yang ditemukan tersebut.

A : olingoli wololo kurikulum 2013 boito?

B : kurikulum boito olami debo susah karena olami ja'o buku boito kendala lio

A : oohh...(ohh)

B : wa lapata'o ami ja'o wolo, ja'o wolo po'olo, ana sikola susah da'a eyi popo terapiolo to ta keke'ingo karna ja'o buku boito.

A : yii olami olo ja mola ngo a'ami sikola yilotapu buku bo 70 skola jadi bo tawewo olo bolo potokopi, makanya menemui kesulitan. 
B : o'o olami olo odito karna nga a'ami sikola botie didiyaluma'a, dipo dadata ta'o buku apalagi boito alami. Tidiyopo boito penilaian liyo susah, susah da'a. Jadi guru boito wakutu lio bomo pulita to boito hemoluwanga penilaian. Lapata'o diyaluwo kesempatan lo guru mo pona'o materi to ta kekeingo.

A : to olami olo odito dema masa'alah boito menilai, mo nilai ngo a'ami sikap boito.

Paparan data di atas mengindikasikan bahwa terdapat jenis deiksis persona dan deiksis tempat. Tuturan "olingoli wololo kurikulum 2013 boito?" menunjukkan konteks bahwa seseorang menanyakan pendapat lawan bicaranya tentang apa pendapat orang tersebut terkait kurikulum 2013 "menurutmu, seperti apakah kurikulum 2013 itu?” . Kata olingoli menunjukkan deiksis persona kedua yang memiliki makna kata sopan karena lawan bicara merupakan orang asing. Hal ini akan terlihat bahwa seseorang tersebut menghargai lawan bicaranya dengan kata olingoli. Selain itu, deiksis persona berikutnya ditemukan ketika lawan bicara menuturkan kata ami yang memiliki makna 'kami. Deiksis persona ini juga tergolong sopan yang memiliki makna bahwa orang tersebut menghargai lawan bicaranya pula. Deiksis berikutnya ditemukan ketika kedua pembicara tersebut membicarakan kondisi kurikulum 2013 yang diterapkan di sekolah mereka masing-masing. Deiksis tempat dalam konteks ini yaitu sikola yang bermakna 'sekolah.

A : londo utonu yio?

B : wuh...londo pangimba, londo po koro'owa madi patu lo dulahu

A : pata'o mailonga?

B : wuh..botie u'alolo dipolo molutu pata'o wololo monga.

A : jiya'a talotubu?

B : ti mayitua donggo hemokaraja, hemo lipu malita.

A : lapata'o jailonga mota toli asi?

B : donggo bilehelo wanu woluwo.

A : lapata'o woluwo?

B : ih..tima'a woluwo amm, mongapo wanu odito, yio jamonga?

A : eh jamonga wau.

$\mathrm{B}$ : yilongola?

A : landingalo wau monga ma butu-butuhu.

B : tima'a pongapo bo ngoindi.

A : de'eh ma butu-butuhu wau dema lapata'o monga ulangi.

B : mawolo mo'o butuhe olemu?

A : mailo butuhe mai tobele.

B : oh mailonga mai yio to bele. 
Paparan di atas merupakan percakapan antara dua orang yang menanyakan dari mana orang tersebut serta apakah orang tersebut sudah makan atau belum. Dalam koteks di atas, penutur pertama menanyakan dengan kalimat "londo utonu yio?" yang menanyakan dari manakah orang tersebut. Penutur pertama ini menggunakan kata "yio" yang berarti 'kamu'. Contoh ini termasuk dalam deiksis persona orang kedua dengan level kesopanan tidak begitu sopan. Hal ini dikarenakan antara kedua penutur ini memiliki umur yang tidak jauh berbeda. Dalam konteks yang sama, penutur kedua pun menggunakan kata wau yang berarti ' $a k u$ ' yang memiliki tingkat kesopanan yang sama pula. Kata yang sama pula dituturkan dalam kalimat "mawolo mo'o butuhe olemu?" yang memiliki makna 'apa yang sudah membuatmu kenyang?'. Kata maytua juga dalam konteks di atas memilik makna sebagai 'istri' yang dikategorikan sebagai deiksis persona. Selain itu, deksis yang ditemukan dalam tuturan di atas yaitu "pangimba" dan "tobele" yang masing-masing memiliki makna 'sawah' dan 'di rumah'.

A : ta Yati pengumuman li taati botie omoluwa?

B : lombu perpisahan lo SMP 9 le Dandi wole Yopi, lapata'o timongolio momaso to SMK 2.

A : lapata'o omoluwa pomasomu?

C : yi'ee...omoluwa te Dandi pomasomu?

$\mathrm{B}$ : nde ema mona'o sama-sma.

C : hhmm

B : dema sama-sama boito mopo maso to SMK.

$\mathrm{C}$ : te Dandi japo masomu to SMA 1

B : de'eh ja mopo maso to SMK 1 wau SMK 2 saja

C : o'o..nilai limongolio ati bo renda, ma pomasolo to SMK 2 tingolio wole Yopi.

Tuturan kalimat-kalimat di atas memiliki beberapa contoh deiksis. Percakapan di atas merupakan percakapan antara kedua ibu dari anak-anaknya yang akan masuk sekolah tingkat atas. Tuturan di atas terdapat beberapa deiksis persona, waktu, dan tempat antara lain nama orang (Yati, Ta Ati, Dandi, dan Yopi) yang dikategorikan dalam deiksis persona. Sebutan "Ta Ati" merupakan sebutan untuk orang yang lebih dihormati. Pada dasarnya nama orang tersebut adalah Ati namun ada tambahan $T a$ yang berarti 'kakak' (untuk perempuan). Selain itu, deiksis waktu dalam konteks di atas yaitu "Lombu" yang berarti 'besok'. Selain itu, kata SMK merupakan deiksi tempat yang berarti sekolah menengah kejuruan.
A : yii o'o gaga utie, wawu yio Inong mayilonga odito kukisi?
B : bulum
A : timola to uwolo tilahu'u ma'a lamitipo.
C : ola'u Ati ma pohutu'u kukisi'u. 
A : pohutuwa loma'o engondi olemu Ati yee, pohutuama'o engondi lapata'o dema sabani, boli tahua sembo lopale.

$\mathrm{C}$ : ola'u tau ta moti na'o-na'o wawu ta ja ti na'o-na'o huliya'u ma bo tolitoliyo poli ola'u boito.

A : te bos

C : ola'u boito lo ngakude, yilopo duluhu ingga huliya ma'a kakudu lami lohilawo, ma Lobanga olo bolo mo sensor mota wawu moheyu mota bongo lapata'o sudah.

B : mamo pobu poli ponula.

$\mathrm{D}$ : Inong

B : jow

$\mathrm{D}$ : ma bilelia lio mai?

B : bulum

Percakapan di atas menceritakan pembicaraan antara 3 orang yang membicarakan penawaran untuk mencicipi makan kue buatan mereka sendiri, tetapi dalam percakapan tersebut juga disampaikan bahwa beberapa dari mereka berencana untuk membuat kue dalam bulan Sya'ban. Dalam konteks tersebut kue yang mereka bicarakan adalah kue dalam rangka persiapan bulan Ramadan dan untuk perayaan hari Raya Idul Fitri. Deiksis yang terkandung dalam percakapan di atas diantaranya adalah deiksis persona dan deksis waktu. Deiksis persona mencakup Inong (nama orang), tilahu' $u$ (memiliki makna aku yang menyimpan), ola' $u$ (punyaku), kukisi'u (kue saya), olemu (untukmu), dan lio (dia). Adapun deiksis waktu yaitu engondi (tadi).

A : mona'o de kota yio motali wolo?

B : motali bo'o pomake to $\mathbf{4 0}$ hari.

A : dulahulo boito 40 hari?

B : dulahu Salasa jam 9

A : mona'o yio?

B : o'o, mona'o

A : Mona'o ito dulota sama-sama mola.

B : oohh

A : lapata'o bo'o pomakemu?

B : sama-sama ito dulota paparia.

A : o’o.., wa'u olo yimaipo mona'o sama-sama ito.

Percakapan di atas merupakan percakapan antara seorang bibi dan keponakannya yang membicarakan acara 40 hari kematian kerabat. Mereka memperbincangkan waktu pelaksanaan acara peringatan 40 kematian kerabat mereka tersebut dan pakaian apa yang hendak akan mereka gunakan. Deiksis yang muncul dalam percakapan di atas, yaitu deiksis persona, waktu, dan tempat. 
Deiksis persona yaitu yio (kamu), ito (kami/kita), pomakemu (yang akan kamu pakai), wa'u (aku). Adapun deiksis waktu yaitu 40 hari (4o hari), Salasa jam 9 (hari Selasa, jam 9), dan deiksis tempat yaitu kota (pusat kota, yang menjadi sebagai pusat perbelanjaan).

\section{PEMBAHASAN}

Penelitian ini bertujuan untuk mengetahui deiksis yang sering digunakan dalam percakapan Bahasa Gorontalo. Deiksis adalah salah satu fenomena sosial yang dapat diamati berdasarkan Bahasa yang digunakan (Abidin et al., 2019; Fitrianti, 2018; Hesti Muliawati, 2016; Kasanova \& Oktasari, 2019; Muliawati, 2017). Penggunaan deiksis dalam Bahasa Gorontalo memiliki ciri khas tersendiri yang membuat berbeda dengan Bahasa melayu lainnya (Lihawa, 2013; Sayama Malabar, 2012; Usman, 2015). Adapun deiksis yang sering digunakan dalam percakapa Bahasa Gorontalo yaitu deiksis persona, deiksis tempat dan deiksis waktu.

Deiksis persona dalam Bahasa Gorontalo terbagi atas orang pertama tunggal yaitu wa'u (aku), watiya (saya), orang pertama jamak yaitu ami/amiyatiya (kami), orang kedua tunggal yaitu yi'o/ tingoli (kamu), orang kedua jamak yaitu tingoli/timongolio (kalian), orang ketiga tunggal yaitu tio/(dia), dan orang ketiga jamak yaitu timongolio (mereka). Terdapat dua dua deiksis dalam setiap persona (Dako, 2015; Usman, 2015) yaitu deiksis yang digunakan sebagai bentuk polite dan impolite. Hal tersebut sangat penting untuk diperhatikan dalam penggunaan deiksis bagi masyarakat Gorontalo. Deiksis persona yang bersifat polite digunakan untuk orang yang lebih tua atau antara istri kepada suami.

Sedangkan untuk deiksisi yang bersifat impolite digunakan antara teman atau kepada yang lebih muda (Afandi, 2013; Bahasa, 2017; Hastuti, 2018; Abdullah , Rahman \& Hamid, 2017; Pimpinan et al., 2017). Selain itu, daiksis tempat yaitu teye/teyamayi (di sini), temota (disana) dan deiksis waktu yaitu yindhie (sekarang), lombu (besok), olango (kemarin), dumodupo (pagi), mohulonu (siang), hui (malam) yang digunakan berdasarkan waktu pandangan ketika tuturan disampaikan.

\section{SIMPULAN}

Berdasarkan hasil analisis data terkait dengan jenis/bentuk dan makna yang telah dipaparkan di atas mengenai deiksis persona, tempat, dan waktu dalam bahasa Gorontalo, penggunaan deiksis persona lebih banyak ditemukan dalam penggunaan percakapan sehari-hari masyarakat Gorontalo dibandingkan dengan penggunaan deiksis waktu dan tempat. Terkait dengan deiksis persona, deiksis ini dibagi dalam 3 jenis, yaitu deiksis persona pertama tunggal, yaitu $w a$ ' $u$ atau watiya (aku atau saya), sedangkan deiksis persona pertama jamak, yaitu ami atau amiyatiya (kami). Makna dari deiksis persona pertama ini berfungsi sebagai pembicara. Deiksis persona kedua tunggal mencakup yi'o atau tingoli (kamu), sedangkan deiksis persona kedua jamak meliputi tingoli atau timongoli (kalian). 
Makna deiksis persona kedua ini berperan sebagai lawan bicara yang dalam penggunaannya memiliki tingkat kesopanan yang berbeda. Deiksis persona ketiga tunggal, yaitu tio (dia), sedangkan deiksis persona ketiga jamak, yaitu timongoliyo (mereka). Makna dari deiksis persona ketiga ini adalah menunjukkan peran sebagai orang yang dibicarakan.

Sementara itu, deiksis tempat, yaitu teye/di sini, temota/di sana, teyamayi/ke sini, dan temota/kesana berarti menunjukkan lokasi ruang dan tempat pembicaraan atau pun lawan bicara. Deiksis tempat ini tidak begitu banyak ditemukan dalam penggunaan tuturan yang disampaikan oleh masyarakat Gorontalo. Hal ini tergantung dari konteks pembicaraan saja. Deiksis waktu, antara lain yindhie/sekarang, lombu/besok, olango/kemarin, dumodupo/pagi, mohulonu/siang, hui/malam yang memiliki makna untuk menunjukkan jara waktu pandang ketika tuturan kata/kalimat disampaikan.

Berdasarkan hasil penelitian dan pembahasan yang telah dipaparkan diatas, maka saran yang diberikan oleh peneliti antara lain:

1. Bagi mahasiswa/pelajar yang mempelajari terkait dengan bahasa Indonesia yang berhubungan dengan bahasa Gorontalo diharapkan agar dapat menambah dan memperkaya teori-teori terkait dengan kajian pragmatik terutama tentang tindak tutur asertif

2. Bagi para pendidik, hasil penelitian ini diharapkan dapat menjadi salah satu sumber maupun rujukan dalam mempersiapkan bahan ajar dan menjadi referensi ilmu pengetahuan dalam kajian pragmatik (bahasa Indonesia-Bahasa Gorontalo), khususnya terkait dengan tindak tutur asertif.

Bagi para peneliti, diharapkan agar bisa lebih dapat menyempurnakan penelitian ini atau pula penelitian ini bisa menjadi rujukan ketika ingin melakukan penelitian dengan kajian yang sama.

\section{DAFTAR PUSTAKA}

Abdulla, N. , Rahman, L. A. \& Hamid, N.A. (2017). Tafsir Pimpinan Ar-Rahman: Tinjauan Terhadap Unsur Kesopanan dalam Sosialinguistik Melayu. Jurnal Sultan Alauddin Sulaiman Shah (JSASS). 5 (2), 135-149.

Abidin, J., Sariban, \& Nisaul Barokati Selirowangi. (2019). Deiksis dalam Novel Merindu Baginda Nabi Karya Habiburrahman El Shirazy. PENTAS: Jurnal Ilmiah Pendidikan Bahasa Dan Sastra Indonesia. 5(1), 74-80. Retrieved from http://e-jurnal.unisda.ac.id/index.php/pentas/article/view/1517

Afandi, A. (2013). Pola Alih Tutur Anak Remaja di Desa Sabang Kecamatan Dampelas. Jurnal Bahasa Dan Sastra Untad. Vol 2, No 1, 1-14. http://jurnal.untad.ac.id/jurnal/index.php/BDS/article/view/2153

Aminuddin, A. P. L. (2016). Deiksis dalam Novel Tembang Ilalang Karya Md. Aminudin. Jurnal Bastra. vol 3(3),1-26. http://dx.doi.org/10.36709/jb.v3i3.2285.

Dako, R. D. R. (2015). Pelestarian Bahasa Gorontalo Melalui Aplikasi Penerjemah Dua Arah (Bahasa Indonesia-Bahasa Gorontalo). Hibah Bersaing (DP2M). 
Riza, L.N. \& Santoso, B. W. J. (2017) Deiksis pada Wacana Sarasehan Habib dengan Masyarakat. (2017). Seloka: Jurnal Pendidikan Bahasa dan Sastra Indonesia. 6 (3) ,273-285. https://journal.unnes.ac.id/sju/index.php/seloka/article/view/20258

Fitrianti, E. (2018). Deiksis Sosial dalam Diskusi Mahasiswa Program Studi Pendidikan Bahasa dan Sastra Indonesia Fakultas Keguruan dan Ilmu Pendidikan Universitas Ekasakti Padang. Unes Journal of Education Scienties. https://doi.org/10.31933/ujes.2.1.071-081.2018

Gustiasari, D. R. (2018). Pengaruh Perkembangan Zaman terhadap Pergeseran Tata Bahasa Indonesia; Studi Kasus pada Pengguna Instagram Tahun 2018. Jurnal Renaissance. 3(2),433-442.

http://www.ejournal-academia.org/index.php/renaissance/article/viewFile/86/53.

Halimah, S. N., \& Hilaliyah, H. (2019). Gaya Bahasa Sindiran Najwa Shihab dalam Buku Catatan Najwa. DEIKSIS. 11(2), 157-165. https://doi.org/10.30998/deiksis.v11i02.3648

Haq, Z. (2017). Penerjemahan Subtitle dari Bahasa Inggris Ke dalam Bahasa Indonesia (Penelitian Analisis Isi pada Subtitle Film Contraband). DEIKSIS. 9 (01), 100-108. https://doi.org/10.30998/deiksis.v9i01.931

Hastuti, S. K. (2018). Pola Komunikasi Kesantunan dan Ketaksantunan Berbahasa antara Dosen dan Mahasiswa (Studi Kasus Sosiopragmatik) di STKIP Budidaya Binjai. Serunai: Jurnal Ilmiah Ilmu Pendidikan. 3(2), 35-43.

https://doi.org/10.37755/sjip.v3i2.25

Hesti Muliawati. (2016). Variasi Bahasa Gaul pada Mahasiswa Unswagati Prodi Pendidikan Bahasa dan Sastra Indonesia Tahun 2016. Deiksis - Jurnal Pendidikan Bahasa dan Sastra Indonesia. 4(2),42-53. http://dx.doi.org/10.33603/deiksis.v4i2.618

Jamil, N. S., \& Yusof, M. (2015). Analisis Deiksis Dialek Kedah. GEMA Online Journal of Language Studies. 5(1), 163-187. https://doi.org/10.17576/gema2015-1501-10.

Kasanova, R., \& Oktasari, A. F. (2019). Kasanova, R., \& Oktasari, A. F. (2019). Nilai-Nilai Didaktis dalam Novel "Matahari Di Atas Gilli" Karya Lintang Sugianto. Deiksis: Jurnal Pendidikan Bahasa Dan Sastra Indonesia. 6(2), 4758. https://doi.org/10.33603/dj.v6i2.1695

Kesumawardani, P. (2015b). Deiksis Persona, Tempat, dan Waktu dalam Novel Pulang Karya Tere Liye (Kajian Pragmatik) dan Relevansinya dengan Pembelajaran Bahasa Indonesia di SMA. Skripsi. Universitas PGRI Yogyakarta. repository.upy.ac.id.

Lihawa, K. (2013). Leksikon dan Nilai Kultur Suwawa-Gorontalo dalam Ritual Momeqati. Bahasa dan Seni. 41(1), 41-51. http://journal2.um.ac.id/index.php/jbs/article/view/95/68.

Merentek, S. H. (2016). Deiksis dalam Film Cinderella: Analisis Pragmatik. Jurnal Elektronik Fakultas Sastra Universitas Sam Ratulangi. 2(1), 2-12. https://ejournal.unsrat.ac.id/index.php/jefs/article/view/12245.

Miranti, I. and F. N. (2014). Evaluasi Nilai- Nilai Pendidikan Karakter dalam Film. Deiksis. 6(2), 101-114 . DOI: http://dx.doi.org/10.30998/deiksis.v6i02.520. 
Muharomah, S. (2016). Penggunaan Bahasa pada Anak Tunanetra: (Pengamatan terhadap Anak Tunanetra melalui Proses Penalaran dalam Kegiatan Tari di Panti Sosial Bina Netra Cahaya Bathin). Deiksis. 8(2), 135-146.

DOI: http://dx.doi.org/10.30998/deiksis.v8i02.721.

Muliawati, H. (2017). Variasi Bahasa Gaul pada Mahasiswa Unswagati Prodi Pendidikan Bahasa dan Sastra Indonesia Tahun 2016. Deiksis: Jurnal Pendidikan Bahasa dan Sastra Indonesia. 4(2), 42-53. https://doi.org/10.33603/deiksis.v4i2.618

Muslikhah Dwihartanti. (2004). Komunikasi yang Efektif. Staff Site Universitas Negeri Yogyakarta. staff.uny.ac.id.

Mustika, H. L. (2012). Analisis Deiksis Persona dalam Ujaran Bahasa Rusia (Suatu Tinjauan Pragmatik). Student E-Journal. 1(1). http://jurnal.unpad.ac.id/ejournal/article/view/1707.

Nafisah, S. (2017). Proses Fonologis dan Pengkaidahannya. Deiksis. 9(1), 70-78. http://dx.doi.org/10.30998/deiksis.v9i01.940.

Nursalim, M. P., \& Alam, S. N. (2019). Pemakaian Deiksis Persona dalam Cerpen di Harian Republika. DEIKSIS. 11(2),121-129. http://dx.doi.org/10.30998/deiksis.v11i02.3654.

Purnama, N. (2011). Dampak Perkembangan Teknologi Komunikasi terhadap Kehidupan Sosial Budaya. Gema Eksos. 5(1), 39-46.

https://www.neliti.com/id/publications/218039/dampak-perkembanganteknologi-komunikasi-terhadap-kehidupan-sosial-budaya

Sartini, N. W. (2009). Menggali Nilai Kearifan Lokal Budaya Jawa Lewat (Bebasan, Saloka, dan Paribasa). Jurnal Logat. V(1),28-37.

http://repository.usu.ac.id/bitstream/handle/123456789/17541/log-apr2009$5 \% 20(4)$.pdf;sequence $=1$

Malabar, S. (2012). Penggunaan Bahasa Transmigran Jawa di Kabupaten Gorontalo. Humaniora.. 24(3). 279-291. https://doi.org/10.22146/jh.1370.

Santoso, T., \& Sabardila, A. (2018). ANALISIS KESALAHAN BERBAHASA PIDATO MAHASISWA MAGISTER PENGKAJIAN BAHASA UNIVERSITAS MUHAMMADIYAH SURAKARTA YANG MEMERANKAN DIRI MENJADI CALON KEPALA DAERAH KABUPATEN BLORA. Jurnal Penelitian Humaniora, 19(2), 17-27.

Suparno, Darista. (2016). "DEIKSIS" dalam Nazam Tarekat arya K.H. Ahmad AR-Rifai Kalisalah Tinjauan Pragmatik. Jurnal Bahasa, Sastra, dan Pendidikan Bahasa dan Sastra Indonesia. 3(2), 2016, 153-172. http://journal.uinjkt.ac.id/index.php/dialektika.

Suparno, Darsita. (2020). "Deiksis" dalam Kumpulan Cerpen Al-Kabuus Tinjauan Sosiopragmatik. Buletin Al-Turas. 21(2),343-365. https://doi.org/10.15408/bat.v21i2.3846

Suseno, I., Supeno, S., \& Miranti, I. (2017). Pengaruh Motivasi, Disiplin Kerja dan Gaya Kepemimpinan Kepala Sekolah terhadap Kinerja Guru Bahasa $\begin{array}{lllll}\text { Inggris SMP DKI Jakarta. DEIKSIS. 9(1), 90-99. } & \text { 9 }\end{array}$ https://doi.org/10.30998/deiksis.v9i01.906

Syamsurizal. (2015). Deiksis dalam Bahasa Pekal di Kabupaten Bengkulu Utara. METALINGUA. 13 (2),229-240.

http://metalingua.kemdikbud.go.id/jurnal/index.php/metalingua/article/download/9/9 
Usman, A. (2015). Frase Nomina Bahasa Gorontalo. Kajian Linguistik. 3( 2), https://doi.org/10.35796/kaling.3.1.2015.8608

Utama, H. (2012). Pemakaian Deiksis Persona dalam Bahasa Indonesia. Jurnal Mahasiswa Jurusan Sastra Indonesia Fakultas Ilmu Budaya, Univaersitas Padjajaran. 1(1),1-15. http://jurnal.unpad.ac.id/ejournal/article/view/1625/1609

Wiratno, T., \& Santosa, R. (2014). Pengantar Linguistik Umum. In: Bahasa, Fungsi Bahasa, dan Konteks Sosial. Universitas Terbuka, Jakarta, pp. 1-19. ISBN 9789790116108. http://repository.ut.ac.id/id/eprint/4240

Yuniarti, N. (2014). Implikatur Percakapan dalam Percakapan Humor. Jurnal Pendidikan Bahasa. 3(2), 225-239 http://dx.doi.org/10.31571/bahasa.v3i2.168. 